\title{
Effect of cytokine treatment on the expression and secretion of brain derived neurotrophic factor in the smooth muscle of the rat colon
}

\author{
MOHAMMAD AL QUDAH ${ }^{1}$, MAHMOUD ALFAQIH ${ }^{1}$, OTHMAN AL-SHBOUL ${ }^{1}$, \\ RAMI SAADEH ${ }^{2}$ and AHMED AL-DWAIRI ${ }^{1}$ \\ Departments of ${ }^{1}$ Physiology and Biochemistry, and ${ }^{2}$ Public Health, \\ School of Medicine, Jordan University of Science and Technology, Irbid 22110, Jordan
}

Received January 15, 2020; Accepted April 13, 2020

DOI: $10.3892 /$ br.2020.1302

\begin{abstract}
The production of pro-inflammatory cytokines and chemokines is increased during inflammatory bowel disease (IBD). Previously, it was demonstrated that brain derived neurotrophic factor (BDNF) expression is increased in experimental models of colitis. BDNF is partially responsible for the structural and functional changes that take place during IBD. However, the exact mechanisms underlying the upregulation of BDNF during gut inflammation are unknown. The aim of the present study was to determine the effects of direct treatment of smooth muscle cells with inflammatory cytokines on the synthesis and secretion of BDNF. BDNF expression and secretion levels were measured using ELISA kits on tissue lysates and on incubation media used to culture the rat colon smooth muscle tissues treated for $24 \mathrm{~h}$ with either tumor necrosis factor (TNF)- $\alpha$ or interleukin (IL)-1 $\beta$. Compared with the control tissue samples, treatment with TNF- $\alpha$ and IL-1 $\beta$ resulted in a significant increase in the protein expression levels of BDNF in the incubated smooth muscle tissue. TNF- $\alpha$ and IL-1 $\beta$ also stimulated the secretion of BDNF. Chelation of intracellular $\mathrm{Ca}^{2+}$ with BABTA-AM prevented the TNF- $\alpha$ and IL-1 $\beta$-induced increase in BDNF protein expression and secretion levels. Furthermore, inhibition of protein kinase A (PKA) significantly reduced BDNF expression levels when treated with cytokines but not secretion. In conclusion, proinflammatory cytokines that are upregulated during IBD, directly stimulated BDNF expression and secretion in a $\mathrm{Ca}^{2+}$ dependent manner. Considering the ability of BDNF to enhance smooth muscle contraction and pain sensation, this autocrine loop may partially explain the characteristic hypercontractility and hypersensitivity associated with IBD.
\end{abstract}

Correspondence to: Dr Mohammad Al Qudah, Department of Physiology and Biochemistry, School of Medicine, Jordan University of Science and Technology, Alramtha Street, Irbid 22110, Jordan E-mail: maalqudah7@just.edu.jo

Key words: colitis, brain derived neurotrophic factor, inflammation, cytokines

\section{Introduction}

Ulcerative colitis (UC) and Crohn's disease (CD), collectively known as inflammatory bowel disease (IBD), are chronic, relapsing, immune-mediated disorders (1). CD is characterized by patchy granulomatous inflammation that may affect any part of the gastrointestinal tract, from the mouth to the anus (2). UC is characterized by a continuous pattern of inflammation that is restricted to the colon (3). The prevalence of IBD has rapidly increased in Europe and North America in the second half of the twentieth century and is becoming more common in the rest of the world, as different countries adopt a Western based diet and lifestyle (4).

The pathogenesis underlying IBD is complex and results from the interaction of environmental factors, genetic variations and intestinal microbiota with the innate and adaptive immune responses (5). Altered immune responses are considered the cornerstone of the pathogenesis underlying IBD (5). For example, in both forms of IBD, the numbers of macrophages and dendritic cells in the lamina propria increase and attain an activated phenotype (5). Furthermore, the production of pro-inflammatory cytokines and chemokines is also enhanced (5). The analysis of the inflamed mucosa from patients with IBD shows an increase in the expression of several cytokines, such as interleukin (IL)-1, IL-6, IL-8 and tumor necrosis factor (TNF)- $\alpha$ (5). These cytokines are hypothesized to subsequently direct the development of an adaptive immune response which is primarily mediated by $\mathrm{T}$ and B lymphocytes (6). The cumulative effect of the above processes eventually leads to IBD.

The production of cytokines serves a central role in the pathogenesis of IBD. Another hallmark of IBD is the dysmotility of the muscular layers of the bowel (7). The specific mechanism underlying the IBD-mediated changes in contractility are currently unknown but may be directly or indirectly associated with the increased production of cytokines. The neurotrophic factor, brain derived neurotrophic factor (BDNF), has been shown to be secreted by smooth muscle cells of the rat colon in a dextran sodium sulphate induced colitis model (8), which enhances the cholinergic contraction of the smooth muscle cells of the colon (9). Taken together, it is hypothesized that cytokines 
produced from the inflammation of the bowel observed in IBD, may directly stimulate the expression of BDNF in the smooth muscle cells of the colon. Secreted BDNF acts in an autocrine manner and affects the contractility of the smooth muscle cells themselves. These observations demonstrate a tentative link between the increased production of inflammatory cytokines in bowel tissues and the ensuing changes in contractility. To support this hypothesis, the aim of the present study was to test the hypothesis that direct treatment of colon smooth muscle cells with inflammatory cytokines increased the synthesis and secretion of BDNF.

\section{Materials and methods}

Animal experiments. All experiments were performed in accordance with the Institutional Animal Care and Use Committee at Jordan University of Science and Technology (approval no. 2019/0023). Male adult Sprague-Dawley rats, weighing 150-200 g, were maintained at the University animal house under with a 12-h light/dark cycle, in polyethylene cages at $-22^{\circ} \mathrm{C}$ and $50 \%$ humidity.

A total of 20 rats were euthanized using $100 \% \mathrm{CO}_{2}$. The colons were dissected, emptied of their contents and placed in cold smooth muscle buffer $(120 \mathrm{mM} \mathrm{NaCl}, 4 \mathrm{mM} \mathrm{KCl}, 2.6 \mathrm{mM}$ $\mathrm{KH}_{2} \mathrm{PO}_{4}, 2.0 \mathrm{mM} \mathrm{CaCl}$, $0.6 \mathrm{mM} \mathrm{MgCl} 2,25 \mathrm{mM}$ HEPES, $14 \mathrm{mM}$ glucose and $2.1 \%$ essential amino mixture; $\mathrm{pH} 7.4$ ). Sections $(2-3 \mathrm{~cm})$ of the colon were removed and mounted onto a glass rod. The fat and mesenteric regions were removed, and the longitudinal muscle was separated from the circular layer by radial abrasion with a Kim wipe. The muscle layers were released from the mucosal/submucosal layers using micro dissection and cut into small sections using surgical scissors. Equal amounts (1.5 g/well) were placed in 6-well plates containing DMEM with penicillin $(200 \mathrm{U} / \mathrm{ml})$, streptomycin $(200 \mu \mathrm{g} / \mathrm{ml})$, gentamycin $\left(100 \mu \mathrm{g} / \mathrm{ml}^{1}\right)$ and amphotericin $\mathrm{B}$ $(2.5 \mu \mathrm{g} / \mathrm{ml})$, and placed in a $37^{\circ} \mathrm{C}$ incubator.

TNF- $\alpha$ and IL-1 $\beta$ exposure. Longitudinal smooth muscle tissues from rat colons were exposed for $24 \mathrm{~h}$ to either medium alone (control, $\mathrm{n}=5$ ) or medium supplemented with $10 \mathrm{ng} / \mathrm{ml}$ recombinant human TNF- $\alpha(\mathrm{n}=3$; R\&D Systems, Inc.; cat. no. 210-TA-005) or $10 \mathrm{ng} / \mathrm{ml} \mathrm{IL}-1 \beta$ (n=3; Sigma-Aldrich; Merck KGaA; cat. no. 11457756001) for $24 \mathrm{~h}$. The roles of $\mathrm{Ca}^{2+}$ and PKA were tested by pre-treating smooth muscle tissues with $1 \mu \mathrm{M}$ BABTA-AM (n=3; R\&D Systems, Inc.) or $1 \mu \mathrm{M}$ PKA inhibitor 6-22 ( $\mathrm{n}=3$; EMD Millipore).

Protein extraction. Smooth muscle tissues were homogenized with solubilization buffer [50 mM Tris-HCL, $150 \mathrm{mM}$ NaCL, 1 mM EDTA, 1\% Triton X-100, $100 \mathrm{mM} \mathrm{NaF}$ and protease/phosphatase inhibitor cocktail (100 $\mu \mathrm{g} \mathrm{ml}^{-1} \mathrm{PMSF}$, $10 \mu \mathrm{g} \mathrm{ml}^{-1}$ aprotinin, $10 \mu \mathrm{g} \mathrm{ml}^{-1}$ leupeptin, $30 \mathrm{mM}$ sodium fluoride and $3 \mathrm{mM}$ sodium vanadate)]. After sonication for $15 \mathrm{sec}$, and centrifugation at 2,000 x g for $10 \mathrm{~min}$ at $4{ }^{\circ} \mathrm{C}$, protein concentrations in the supernatant were determined using a DC protein assay kit according to the manufacturer's protocol (Bio-Rad Laboratories, Inc).

ELISA. Secreted BDNF and BDNF protein levels in smooth muscle tissues were measured using sandwich ELISA
(Promega BDNF Emax immunoassay; Promega Corporation; cat. no. G7611) according to the manufacturer's protocol. The samples were acidified to a $\mathrm{pH}<3.0$ with $1 \mathrm{M} \mathrm{HCI}$ for $15 \mathrm{~min}$ and then neutralized to $\mathrm{pH} 7.6$ prior to use for ELISA. The antibody used was specific for BDNF with $<3 \%$ cross reactivity with nerve growth factor, NT-3 and NT-4, with no cross reactivity with PACAP, SP, VIP, secretin and somatostatin according to manufacturer's protocol. The limit for detection with ELISA is $4 \mathrm{ng} / \mathrm{ml}$ and the range is $4-500 \mathrm{ng} / \mathrm{ml}$. Briefly, ELISA plates were coated with anti-BDNF mAb $(1: 1,000)$ and incubated overnight at $4{ }^{\circ} \mathrm{C}$. The following day, the plate was washed and blocked with blocking buffer (Promega Corporation). A total of $100 \mu \mathrm{l}$ BDNF standard or sample was added to each well and incubated for $2 \mathrm{~h}$ at room temperature. The plate was washed, and $100 \mu l$ anti-BDNF pAb (1:500) was added to each well and incubated at room temperature for $2 \mathrm{~h}$. After washing, $100 \mu \mathrm{l}$ of diluted anti-immunoglobulin Y-horseradish peroxidase conjugate (1:200) was added to each well and developed with TMB solution and 1 M HCI. The absorbance was measured at $450 \mathrm{~nm}$ using an ELISA microplate reader (elx-800; BioTek Instruments, Winooski, VT, USA), and the concentration of BDNF in the samples was calculated using a standard curve. Data are expressed relative to the total protein concentration and compared with the control, TNF- $\alpha$ and IL- $1 \beta$ treated groups.

Statistical analysis. Data are presented as the mean \pm the standard error of the mean. Each experiment used at least three animals and was repeated three times. GraphPad PRISM version 8 (GraphPad Software, Inc.) was used for statistical analysis. ANOVA with a post hoc Tukey's test was used for multiple comparisons. $\mathrm{P}<0.05$ was considered to indicate a statistically significant difference.

\section{Results}

Effect of TNF- $\alpha$ and IL-1 $\beta$ on BDNF expression in the longitudinal muscles of the rat colon. The effect of TNF- $\alpha$ and IL-1 $\beta$ on BDNF protein content in smooth muscle tissues was evaluated. Both TNF- $\alpha$ and IL-1 $\beta$ significantly upregulated BDNF protein expression levels compared with the control (control, 111.7 \pm 8.11 ; TNF- $\alpha, 228 \pm 29.51, \mathrm{P}=0.0096$; IL-1 $\beta$, $175.8 \pm 12.03, \mathrm{P}=0.0057$; Fig. 1). The effect of TNF- $\alpha$ was greater than that of IL-1 $\beta$, but was not statistically significant.

Effect of TNF- $\alpha$ and IL-1 $\beta$ on BDNF secretion in the longitudinal smooth muscle of rat colons. To study the effects of TNF- $\alpha$ and IL-1 $\beta$ on the secretion of BDNF, longitudinal smooth muscle tissues were treated with TNF- $\alpha$ and IL- $1 \beta$ for $24 \mathrm{~h}$ and the quantity of BDNF release into the media was determined using ELISA. After $24 \mathrm{~h}$ of incubation with either of the cytokines, secretion of BDNF was significantly increased compared with the control (control, 36.67 \pm 6.888 ; TNF- $\alpha, 75.33 \pm 7.42, \mathrm{P}=0.0067$; IL-1 $\beta, 64.25 \pm 4.54, \mathrm{P}=0.0246$; Fig. 2). The increase in BDNF secretion induced by TNF- $\alpha$ was greater than that of IL-1 $\beta$, but was not statistically significant.

Role of $\mathrm{Ca}^{2+}$ and PKA in mediating the effects of $I L-1 \beta$ on $B D N F$ expression in longitudinal muscle tissues. To determine 


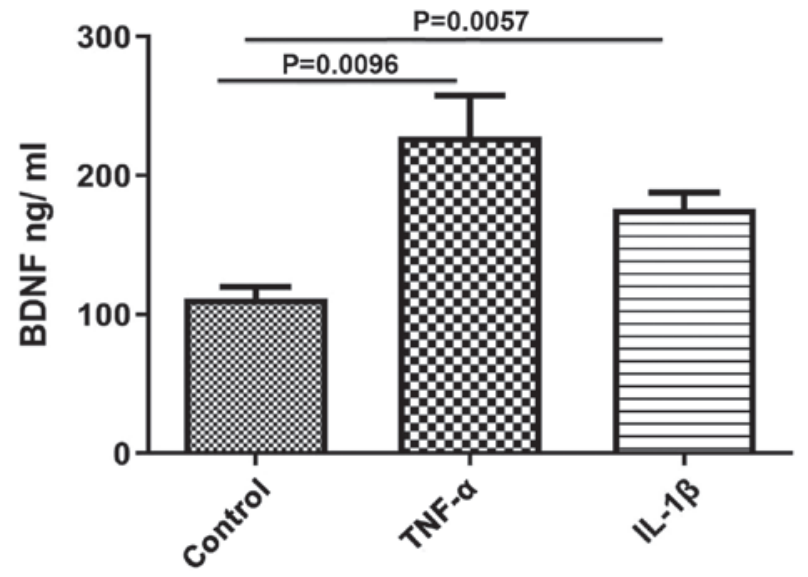

Figure 1. Expression of BDNF synthesis induced by TNF- $\alpha$ and IL-1 $\beta$. Incubation of rat colon smooth muscle tissue with $10 \mathrm{ng} / \mathrm{ml} \mathrm{TNF-} \alpha$ and with $10 \mathrm{ng} / \mathrm{ml}$ of IL- $1 \beta$ for $24 \mathrm{~h}$ increased expression of BDNF. Data are presented as the mean \pm the standard error of the mean. BDNF; brain derived neurotrophic factor; TNF- $\alpha$, tumor necrosis factor- $\alpha$; IL- $1 \beta$, interleukin- $1 \beta$.

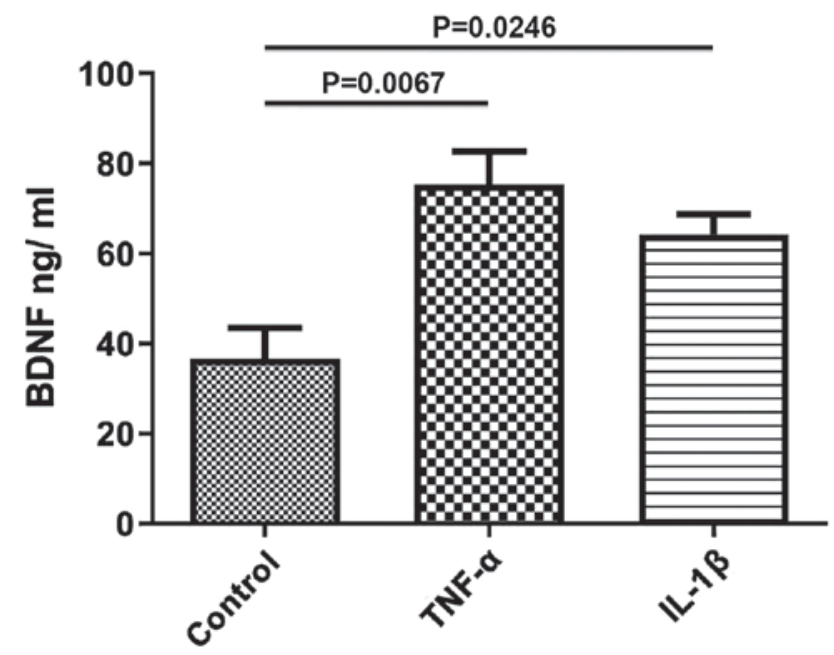

Figure 2. Secretion of BDNF induced by TNF- $\alpha$ and IL-1 $\beta$. Incubation of rat colon smooth muscle tissues with $10 \mathrm{ng} / \mathrm{ml} \mathrm{TNF}-\alpha$ or $10 \mathrm{ng} / \mathrm{ml}$ of IL- $1 \beta$ for $24 \mathrm{~h}$ increased secretion of BDNF. Data are presented as the mean \pm the standard error of the mean. BDNF, brain derived neurotrophic factor; TNF- $\alpha$, tumor necrosis factor- $\alpha$; IL-1 $\beta$, interleukin- $1 \beta$.

the mechanism of action underlying the IL-1 $\beta$-mediated increase in BDNF expression, the roles of $\mathrm{Ca}^{2+}$ and PKA were both investigated, as both are involved in the responses evoked by IL-1 $\beta$, and are known activators of BDNF gene transcription $(10,11)$. Incubation of longitudinal muscle tissues with IL- $1 \beta$ for $24 \mathrm{~h}$ in the presence of $1 \mu \mathrm{M}$ BAPTA-AM to chelate $\mathrm{Ca}^{2+}$, abrogated the ability of IL-1 $\beta$ to increase BDNF expression (control, 111.7 \pm 8.11 ; IL-1 $\beta, 175.8 \pm 12.03, \mathrm{P}=0.0052$ vs. control; IL-1 $\beta$-BABTA-AM, $118.0 \pm 4.041, \mathrm{P}=0.913$ vs. control; $\mathrm{P}=0.0099$, IL-1 $\beta$ vs. IL-1 $\beta$-BABTA-AM; Fig. 3). However, the effect of $1 \mu \mathrm{M}$ of PKA inhibitor 6-22 Amide did not significantly alter the effect of IL-1 $\beta$ on BDNF expression (control, 111.7 \pm 8.11 ; IL-1 $\beta, 175.8 \pm 12.03$; IL-1 $\beta$-PKA inhibitor, $152.3 \pm 10.48 ; \mathrm{P}=0.3720$, IL-1 $\beta$ vs. IL-1 $\beta-\mathrm{PKA})$.

Role of $\mathrm{Ca}^{2+}$ and PKA inmediating the effect of TNF- $\alpha$ on BDNF expression in longitudinal muscle tissues. To determine the

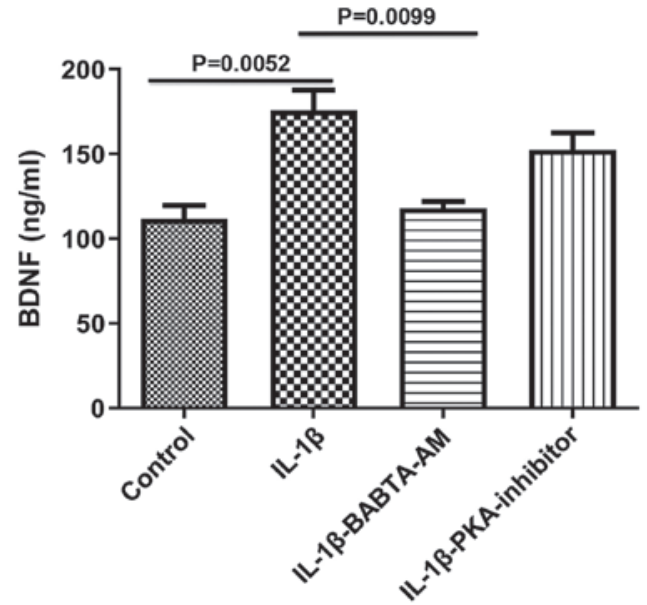

Figure 3. Effect of BAPTA-AM and PKA inhibitors on the expression of BDNF induced by $10 \mathrm{ng} / \mathrm{ml} \mathrm{IL-1 \beta}$. Incubation of smooth muscle tissues for $24 \mathrm{~h}$ with the $\mathrm{Ca}^{2+}$ chelating agent BAPTA-AM significantly reduced the increase in BDNF expression levels induced by $10 \mathrm{ng} / \mathrm{ml} \mathrm{IL-1 \beta}$. Treatment with PKA decreased BDNF expression levels. Data are presented as the mean \pm the standard error of the mean. BDNF, brain derived neurotrophic factor; IL-1 $\beta$, interleukin-1 $\beta$; PKA, protein kinase A.

mechanism of action underlying TNF- $\alpha$ on BDNF expression, the role of $\mathrm{Ca}^{2+}$ and PKA was investigated, as both are associated with TNF- $\alpha$-mediated effects. Incubation of longitudinal muscle tissues with $10 \mathrm{ng} / \mathrm{ml} \mathrm{TNF}-\alpha$ for $24 \mathrm{~h}$ in the presence of $1 \mu \mathrm{M}$ BAPTA-AM to chelate $\mathrm{Ca}^{2+}$ abrogated the ability of TNF- $\alpha$ to increase BDNF expression (control, 111.7 \pm 8.11 ; TNF- $\alpha, 228 \pm 29.51, P=0.0096$ vs. control; TNF- $\alpha$-BAPTA-AM, $115.7 \pm 8.686, \mathrm{P}=0.6934$ vs. control; $\mathrm{P}=0.0316$, TNF- $\alpha$ vs. TNF- $\alpha$-BAPTA-AM; Fig. 4). Furthermore, PKA inhibition with $1 \mu \mathrm{M}$ of 6-22 Amide abolished the effects of TNF- $\alpha$ on BDNF expression (control, 111.7 \pm 8.11 ; TNF- $\alpha, 23 \pm 29.51$, $\mathrm{P}=0.0096$ vs. control; TNF- $\alpha-\mathrm{PKA}$ inhibitor, $129 \pm 6.35$, $\mathrm{P}=0.9834$ vs. control; $\mathrm{P}=0.0110, \mathrm{TNF}-\alpha$ vs. TNF- $\alpha-\mathrm{PKA})$.

Role of $\mathrm{Ca}^{2+}$ and PKA in mediating the effect of $I L-1 \beta$ on $B D N F$ secretion from longitudinal muscle tissues. As BDNF is secreted in an activity dependent manner in response to elevated intracellular $\mathrm{Ca}^{2+}$, the role of general $\mathrm{Ca}^{2+}$ on $\mathrm{BDNF}$ secretion in response to IL-1 $\beta$ was assessed. Incubation of rat smooth muscle tissue for $24 \mathrm{~h}$ with IL- $1 \beta$ in the presence of $1 \mu \mathrm{m}$ of BAPTA-AM resulted in complete inhibition of IL-1 $\beta$ on BDNF secretion (control, 36.67 \pm 6.89 ; IL-1 $\beta, 64.25 \pm 4.54, \mathrm{P}=0.0327$ vs. control; IL-1 $\beta$-BAPTA-AM, 32.67 $\pm 8.57, \mathrm{P}=0.9656$ vs. control; $\mathrm{P}=0.0157$, IL-1 $\beta$ vs. IL-1 $\beta$-BAPTA-AM; Fig. 5). Treatment with PKA did not significantly decrease BDNF secretion (control, 36.67 \pm 6.888 ; IL-1 $\beta, 64.25 \pm 4.54$; IL-1 $\beta$-PKA inhibitor, $50.67 \pm 2.60 ; \mathrm{P}=0.3882$, IL-1 $\beta$ vs. IL-1 $\beta$-PKA).

Role of $\mathrm{Ca}^{2+}$ and PKA in mediating the effect of TNF- $\alpha$ on $B D N F$ secretion from longitudinal muscle tissues. Incubation of rat smooth muscle tissues for $24 \mathrm{~h}$ with TNF- $\alpha$ in the presence of $1 \mu \mathrm{m}$ of BAPTA-AM abolished the ability of TNF- $\alpha$ to increase BDNF secretion (control, 36.67 \pm 6.89 ; TNF- $\alpha$, $75.33 \pm 7.42, \mathrm{P}=0.0188$ vs. control; TNF- $\alpha$-BAPTA-AM, $41 \pm 7.55, \mathrm{P}=0.0 .6934$ vs. control; $\mathrm{P}=0.0303$, TNF- $\alpha$ vs. TNF- $\alpha$-BAPTA-AM; Fig. 6). However, $1 \mu \mathrm{M}$ of 6-22 Amide did not significantly inhibit BDNF secretion induced by 


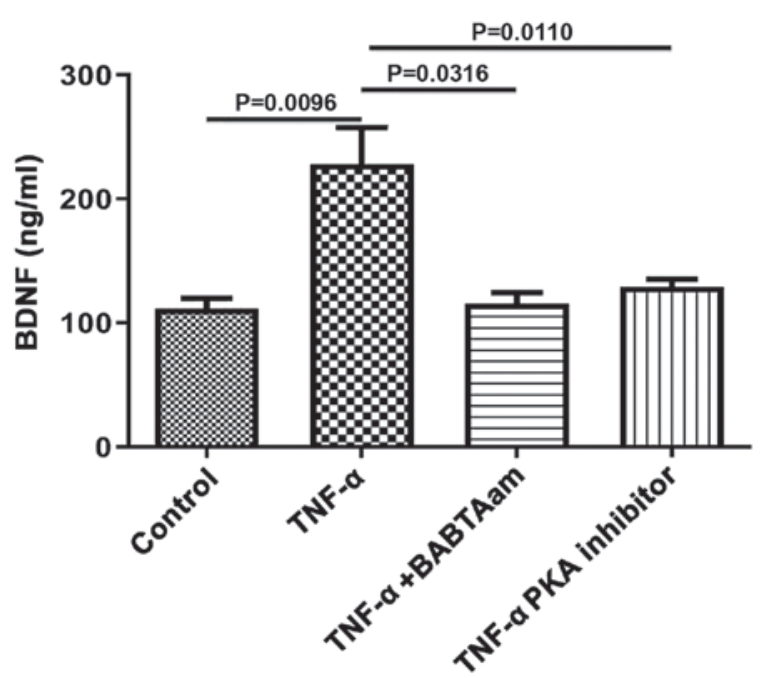

Figure 4. Effect of BAPTA-AM and PKA inhibitors on the expression of BDNF induced by $10 \mathrm{ng} / \mathrm{ml}$ TNF- $\alpha$. Incubation of smooth muscle tissues for $24 \mathrm{~h}$ with the $\mathrm{Ca}^{2+}$ chelating agent BAPTA-AM or a PKA inhibitor both abolished the increase in BDNF expression induced by $10 \mathrm{ng} / \mathrm{ml} \mathrm{TNF}-\alpha$. Data are presented as the mean \pm the standard error of the mean. BDNF, brain derived neurotrophic factor; TNF- $\alpha$, tumor necrosis factor- $\alpha$; PKA, protein kinase A.

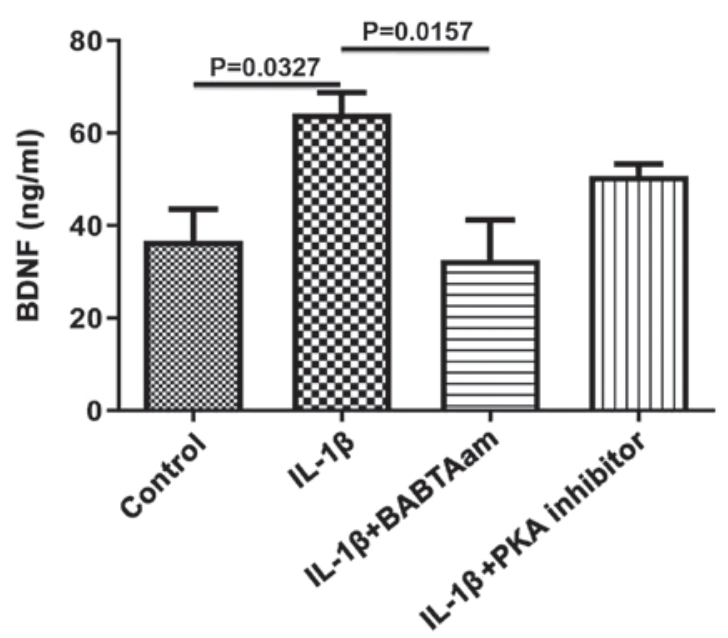

Figure 5. Effect of BAPTA-AM and PKA inhibitors on the secretion of BDNF induced by $10 \mathrm{ng} / \mathrm{ml}$ IL-1 $\beta$. Incubation of smooth muscle tissues for $24 \mathrm{~h}$ with the $\mathrm{Ca}^{2+}$ chelating agent BAPTA-AM abolished the increase in BDNF secretion induced by $10 \mathrm{ng} / \mathrm{ml}$ IL-1 $\beta$. PKA inhibitor did not significantly affect secretion induced by IL-1 $\beta$. Data are presented as the mean \pm the standard error of the mean. BDNF, brain derived neurotrophic factor; IL-1 $\beta$, interleukin-1 $\beta$; PKA, protein kinase A.

TNF- $\alpha$ (control, $36.67 \pm 6.89$; TNF- $\alpha, 75.33 \pm 7.42, \mathrm{P}=0.0188$ vs. control; TNF- $\alpha$-PKA inhibitor, $68.00 \pm 11.68, \mathrm{P}=0.0785$ vs. control; $\mathrm{P}=0.9283$, TNF- $\alpha$ vs. TNF- $\alpha$-PKA).

\section{Discussion}

In the present study, it was demonstrated that the exogenous proinflammatory cytokines, TNF- $\alpha$ and IL-1 $\beta$, upregulated BDNF protein expression and secretion in rat colon smooth muscle tissues. Furthermore, the expression and secretion of BDNF by TNF- $\alpha$ and IL-1 $\beta$ were likely $\mathrm{Ca}^{2+}$-dependent. Finally the effect of TNF- $\alpha$ on the expression and secretion of BDNF was regulated by the cAMP/PKA pathway as well.

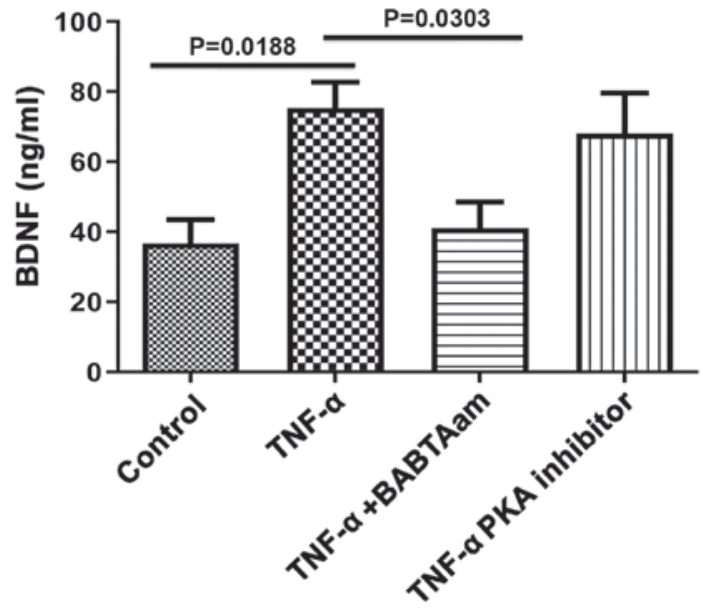

Figure 6. Effect of BAPTA-AM and PKA inhibitors on the secretion of BDNF induced by $10 \mathrm{ng} / \mathrm{ml}$ TNF- $\alpha$. Incubation of smooth muscle tissues for $24 \mathrm{~h}$ with the $\mathrm{Ca}^{2+}$ chelating agent BAPTA-AM abolished the increase in BDNF secretion induced by $10 \mathrm{ng} / \mathrm{ml}$ TNF- $\alpha$. BDNF secretion was not significantly affected by PKA inhibitor treatment. Data are presented as the mean \pm the standard error of the mean. BDNF, brain derived neurotrophic factor; TNF- $\alpha$, Tumor Necrosis Factor- $\alpha$; PKA, protein kinase A.

Previously, it has been shown that BDNF and its receptors are present in adult rat colon smooth muscle, and its expression is increased in inflammatory diseases such as UC $(8,12)$. Furthermore, exogenous BDNF enhances cholinergic contraction of the smooth muscle cells associated with IBD (9). In the present study, it was demonstrated that TNF- $\alpha$ and IL-1 $\beta$ significantly upregulated BDNF levels in rat colon smooth muscle tissues. In agreement with the results of the present study, inflammatory cytokines enhanced BDNF expression and secretion in airway smooth muscle cells (13). The effect of these cytokines may underlie functional and structural changes which take place during bowel inflammation. For example, the reported changes in gut motility during colitis and in response to inflammatory cytokines (14) may be due to the increase in expression/secretion of BDNF which was induced by TNF- $\alpha$ and IL-1 $\beta$, as demonstrated in the present study. The effect of BDNF on gut motility is well established. BDNF enhances stool frequency in patients treated with a higher dose of BDNF, enhances gastrointestinal and colonic transit in human subjects, accelerates myoelectric activity in the gastrointestinal tract and enhances peristalsis in the rat colon (15-18). Furthermore, BDNF may account for the abdominal pain and visceral hypersensitivity experienced by patients with gut inflammation (19). Intraperitoneal BDNF injections results in increased pain sensation in response to colon distension in healthy rats, and administration of BDNF antibodies inhibited visceral hypersensitivity in experimental colitis (19), and BDNF heterogeneous knockout animals experienced notably less pain compared with wild type mice in a model of colitis (20). Furthermore, BDNF increases the expression of calcitonin gene-related peptide during colitis, which is considered a pain mediator (21). The results of the present study suggest that TNF- $\alpha$ and IL-1 $\beta$ may underlie the increase in BDNF expression.

An additional aim of the present study was to delineate the mechanisms underlying the increase in BDNF expression and secretion mediated by proinflammatory cytokines. 
BDNF expression by both TNF- $\alpha$ and IL-1 $\beta$ was $\mathrm{Ca}^{2+}$ and PKA dependent. BDNF gene expression is under the control of intracellular $\mathrm{Ca}^{2+}$ and PKA levels (22). Stimuli that result in an increase in the intracellular $\mathrm{Ca}^{2+}$ levels activate BDNF transcription and synthesis by activating $\mathrm{Ca}^{2+} /$ calmodulin, which phosphorylates calmodulin-dependent protein kinase I (CaMKII). CaMKII, in turn, phosphorylates cAMP response element-binding protein (CREB) which results in BDNF transcription and translation (23). Although in the present study, $\mathrm{Ca}^{2+}$ levels were not measured in response to TNF- $\alpha$ and IL-1 $\beta$, it has previously been shown that these cytokines may increase intracellular $\mathrm{Ca}^{2+}$ levels in various types of cells, including smooth muscle cells (24). In agreement with the results of the present study, TNF- $\alpha$ upregulates BDNF protein in primary astrocytes (25), monocytes (26), neurons (27) and smooth muscle cells (13). In airway smooth muscle cells, elevation of intracellular $\mathrm{Ca}^{2+}$ and PKA are essential for TNF- $\alpha$ induced BDNF synthesis (13).

BDNF is secreted in an activity dependent manner that is regulated by intracellular $\mathrm{Ca}^{2+}$ levels (28). In the present study, it was shown that the TNF- $\alpha$ and IL- $1 \beta$ induced BDNF release was inhibited by the chelation of intracellular and extracellular $\mathrm{Ca}^{2+}$ using BAPTA-AM. As the source of $\mathrm{Ca}^{2+}$ was not investigated, future studies should use different pharmacological inhibitors of intracellular and extracellular $\mathrm{Ca}^{2+}$ routes, to elucidate the pathways involved in cytokine induced BDNF release.

BDNF may act in a positive feedback loop to induce its synthesis and release (28). BDNF activates three primary signaling pathways; ERK, PI3K and phospholipase C, resulting in increases in intracellular $\mathrm{Ca}^{2+}$ levels (29). Thus in future studies the effects of these cytokines in the presence and absence of tropomyosin-related kinase B should be investigated to assess this possibility. In airway smooth muscle cells, cytokine-mediated BDNF release was $\mathrm{Ca}^{2+}$ dependent and involved a positive feedback mechanism mediated by BDNF, acting in an autocrine and paracrine manner (13), which may also apply to colon smooth muscle cells.

The reported role of $\mathrm{cAMP} / \mathrm{PKA}$ in cytokine-induced BDNF synthesis and release is supported by several previous studies. It was previously shown that substance P (SP) and pituitary adenylate cyclase activating peptide (PACAP) induced BDNF synthesis in intestinal smooth muscle cells in a cAMP/PKA dependent manner (30). PKA inhibition resulted in reduced BDNF synthesis in response to SP or PACAP treatment (30). In neurons from rat hippocampi, BDNF expression was under the control of PKA activation and the subsequent phosphorylation of CREB (31-33) these data demonstrate that cytokines stimulation of BDNF synthesis in colon smooth muscle cells is PKA dependent as well.

In conclusion, TNF- $\alpha$ and IL- $1 \beta$ upregulated BDNF synthesis and release in rat colon smooth muscle cells. Both cytokines depend on $\mathrm{Ca}^{2+}$ for their action on BDNF synthesis and release; however, PKA may have been more involved in BDNF synthesis rather than release. These data may highlight novel potential avenues for treatment of IBD, by targeting BDNF.

\section{Acknowledgements}

Not applicable.

\section{Funding}

The present study was supported by a grant from the Jordan University of Science and Technology (grant no. 2019/0102).

\section{Availability of data and materials}

The datasets used and/or analyzed during the present study are available from the corresponding author on reasonable request.

\section{Authors' contributions}

MAQ conceived the study and wrote the manuscript. MA designed the study and collected the data. OAS generated the figures and supervised the study. RS performed the statistical analysis. AAD designed the experiments and revised the manuscript. All authors have read and approved the final manuscript.

\section{Ethics approval and consent to participate}

All experiments were performed in accordance with the Institutional Animal Care and Use Committee at Jordan University of Science and Technology (approval no. 2019/0023).

\section{Patient consent for publication}

Not applicable.

\section{Competing interests}

The authors declare that they have no competing interests.

\section{References}

1. Hanauer SB: Inflammatory bowel disease: Epidemiology, pathogenesis, and therapeutic opportunities. Inflamm Bowel Dis 12 (Suppl 1): S3-S9, 2006.

2. Loftus EV, Schoenfeld P and Sandborn WJ: The epidemiology and natural history of Crohn's disease in population-based patient cohorts from North America: A systematic review. Aliment Pharmacol Ther 16: 51-60, 2002.

3. Sloan WP Jr, Bargen FA and Gage RP: Life histories of patients with chronic ulcerative colitis: A review of 2,000 cases. Gastroenterology 16: 25-38, 1950.

4. Loftus EV Jr: Clinical epidemiology of inflammatory bowel disease: Incidence, prevalence, and environmental influences. Gastroenterology 126: 1504-1517, 2004.

5. Sobolewska-Włodarczyk A and Włodarczyk M: Pathogenesis of IBD. In: Introduction to Gastrointestinal Diseases Vol. 1. Springer, pp 83-93, 2017.

6. Múzes G, Molnár B, Tulassay Z and Sipos F: Changes of the cytokine profile in inflammatory bowel diseases. World J Gastroenterol 18: 5848-5861, 2012.

7. Vermillion DL, Huizinga JD, Riddell RH and Collins SM: Altered small intestinal smooth muscle function in Crohn's disease. Gastroenterology 104: 1692-1699, 1993.

8. Al-Qudah M, Shammala DA, Al-Dwairi A, Al-Shboul O and Mustafa AG: Dextran sodium sulphate (DSS)-induced colitis alters the expression of neurotrophins in smooth muscle cells of rat colon. Physiol Res 66: 1009-1020, 2017.

9. Al-Qudah M, Anderson CD, Mahavadi S, Bradley ZL, Akbarali HI, Murthy KS and Grider JR: Brain-derived neurotrophic factor enhances cholinergic contraction of longitudinal muscle of rabbit intestine via activation of phospholipase C. Am J Physiol Liver Physiol 306: G328-G337, 2013. 
10. Zheng F, Zhou X, Luo Y, Xiao H, Wayman G and Wang H: Regulation of brain-derived neurotrophic factor exon IV transcription through calcium responsive elements in cortical neurons. PLoS One 6: e28441, 2011.

11. Xue W, Wang W, Gong T, Zhang H, Tao W, Xue L, Sun Y, Wang $F$ and Chen G: PKA-CREB-BDNF signaling regulated long lasting antidepressant activities of Yueju but not ketamine. Sci Rep 6: 26331, 2016.

12. Al-Qudah M, Shammala DA, Al-Dwairi A and Al-Shboul O: Differential expression of neurotrophins in (DSS)-induced colitis in smooth muscle of rat colon. J Teknol 78, 2016.

13. Aravamudan B, Thompson MA, Pabelick CM and Prakash YS: Mechanisms of BDNF regulation in asthmatic airway smooth muscle. Am J Physiol Lung Cell Mol Physiol 311: L270-L279, 2016.

14. Nalli AD, Kumar DP, Mahavadi S, Al-Shboul O, Alkahtani R, Kuemmerle JF, Grider JR and Murthy KS: Hypercontractility of intestinal longitudinal smooth muscle induced by cytokines is mediated by the nuclear factor-kappaB/AMP-activated kinase/myosin light chain kinase pathway. J Pharmacol Exp Ther 350: 89-98, 2014.

15. A controlled trial of recombinant methionyl human BDNF in ALS: The BDNF Study Group (Phase III). Neurology 52: 1427-1433, 1999.

16. Coulie B, Szarka LA, Camilleri M, Burton DD, McKinzie S, Stambler N and Cedarbaum JM: Recombinant human neurotrophic factors accelerate colonic transit and relieve constipation in humans. Gastroenterology 119: 41-50, 2000.

17. Chai NL, Dong L, Li ZF, Du KX, Wang JH, Yan LK and Dong XL: Effects of neurotrophins on gastrointestinal myoelectric activities of rats. World J Gastroenterol 9: 1874-1877, 2003.

18. Grider JR, Piland BE, Gulick MA and Qiao LY: Brain-derived neurotrophic factor augments peristalsis by augmenting 5-HT and calcitonin gene-related peptide release. Gastroenterology 130: 771-780, 2006.

19. Delafoy L, Gelot A, Ardid D, Eschalier A, Bertrand C, Doherty AM and Diop L: Interactive involvement of brain derived neurotrophic factor, nerve growth factor, and calcitonin gene related peptide in colonic hypersensitivity in the rat. Gut 55: 940-945, 2006.

20. Xia CM, Gulick MA, Yu SJ, Grider JR, Murthy KS, Kuemmerle JF, Akbarali HI and Qiao LY: Up-regulation of brain-derived neurotrophic factor in primary afferent pathway regulates colon-to-bladder cross-sensitization in rat. J Neuroinflammation 9: 30, 2012.

21. Hashmi F, Liu M, Shen S and Qiao LY: Phospholipase C gamma mediates endogenous brain-derived neurotrophic factor-regulated calcitonin gene-related peptide expression in colitis-induced visceral pain. Mol Pain 12: 1744806916657088, 2016.
22. West AE, Chen WG, Dalva MB, Dolmetsch RE, Kornhauser JM, Shaywitz AJ, Takasu MA, Tao X and Greenberg ME: Calcium regulation of neuronal gene expression. Proc Natl Acad Sci USA 98: 11024-11031, 2001.

23. Yan X, Liu J, Ye Z, Huang J, He F, Xiao W, Hu X and Luo Z: CaMKII-mediated CREB phosphorylation is involved in $\mathrm{Ca} 2+-$ induced BDNF mRNA transcription and neurite outgrowth promoted by electrical stimulation. PLoS One 11: e0162784, 2016.

24. Prakash YS, Thompson MA and Pabelick CM: Brain-derived neurotrophic factor in TNF- $\alpha$ modulation of $\mathrm{Ca} 2+$ in human airway smooth muscle. Am J Respir Cell Mol Biol 41: 603-611, 2009.

25. Saha RN, Liu X and Pahan K: Up-regulation of BDNF in astrocytes by TNF- $\alpha$ : A case for the neuroprotective role of cytokine. J Neuroimmune Pharmacol 1: 212-222, 2006.

26. Schulte-Herbrüggen $\mathrm{O}$, Nassenstein $\mathrm{C}$, Lommatzsch $\mathrm{M}$, Quarcoo D, Renz H and Braun A: Tumor necrosis factor-alpha and interleukin-6 regulate secretion of brain-derived neurotrophic factor in human monocytes. J Neuroimmunol 160: 204-209, 2005

27. Murphy PG, Borthwick LA, Altares M, Gauldie J, Kaplan D and Richardson PM: Reciprocal actions of interleukin-6 and brain-derived neurotrophic factor on rat and mouse primary sensory neurons. Eur J Neurosci 12: 1891-1899, 2000.

28. Al-Qudah MA and Al-Dwairi A: Mechanisms and regulation of neurotrophin synthesis and secretion. Neurosciences 21: 306, 2016.

29. Aravamudan B, Thompson MA, Pabelick C and Prakash YS: Secretion of brain derived neurotrophic factor is regulated by inflammation-induced signals in asthmatic airway smooth muscle cells. In: A109. REMODELING AND THE MATRIX. American Thoracic Society, pp. A2839, 2016.

30. Al-Qudah M, Alkahtani R, Akbarali HI, Murthy KS and Grider JR: Stimulation of synthesis and release of brain-derived neurotropic factor from intestinal smooth muscle cells by substance $\mathrm{P}$ and pituitary adenylate cyclase-activating peptide. Neurogastroenterol Motil 27: 1162-1174, 2015.

31. Zhong Y, Chen J, Li L, Qin Y, Wei Y, Pan S, Jiang Y, Chen J and Xie Y: PKA-CREB-BDNF signaling pathway mediates propofol-induced long-term learning and memory impairment in hippocampus of rats. Brain Res 1691: 64-74, 2018.

32. Zhen JL, Chang YN, Qu ZZ, Fu T, Liu JQ and Wang WP: Luteolin rescues pentylenetetrazole-induced cognitive impairment in epileptic rats by reducing oxidative stress and activating PKA/CREB/BDNF signaling. Epilepsy Behav 57: 177-184, 2016.

33. Park $\mathrm{H}$ and Kaang BK: Balanced actions of protein synthesis and degradation in memory formation. Learn Mem 26: 299-306, 2019. 